\title{
Formulasi, Evaluasi Sifat Fisik, dan Uji Efektivitas Tabir Surya Losion Ekstrak Buah Jamblang (Syzygium cumini (L.) Skeels)
}

\section{Formulation, Physical Properties, and Sunscreen Effectivity of Lotion with Java Plum (Syzygium cumini (L.) Skeels) Fruit Extract as the Active Ingredient}

\author{
Zainur Rahman Hakim*, Puteri Khazizah Isnaini, Erza Genatrika \\ Fakultas Farmasi, Universitas Muhammadiyah Purwokerto \\ Jl. KH. Ahmad Dahlan, Dukuhwaluh, Kembaran, Purwokerto 53182, Indonesia \\ *Corresponding author email: zainuralmubarok7@ump.ac.id
}

Received 07-01-2020 Accepted 18-05-2020 Available online 01-07-2020

\begin{abstract}
ABSTRAK
Angka kejadian kanker kulit yang dijumpai di Indonesia cukup tinggi sekitar 5,9-7,8\%. Salah satu penyebabnya adalah paparan sinar UV berlebihan pada kulit. Dengan demikian diperlukan adanya suatu produk yang dapat melindungi kulit dari bahaya sinar UV. Pada penelitian terdahulu buah jamblang dilaporkan memiliki nilai faktor perlindungan terhadap matahari (sun protection factor/SPF) yaitu $2,278 \pm 0,25 \%$ yang berpotensi untuk dibuat sediaan tabir surya. Penelitian ini bertujuan untuk membuat formula losion ekstrak buah jamblang (Syzygium cumini (L.) Skeels) yang kemudian diuji karakteristik fisik dan efektivitas tabir surya dari produk tersebut. Buah jamblang kering dihaluskan dan diayak pada 40/60 mesh sehingga didapatkan serbuk simplisia dan dihitung rendemennya. Sebanyak $100 \mathrm{~g}$ serbuk diekstraksi dengan metode remaserasi dalam pelarut etanol $70 \%$ selama $3 \times 24$ jam dan ditambahkan secukupnya $\mathrm{HCl} 37 \%$ hingga $\mathrm{pH}$ 1. Maserat kemudian disaring dan dipekatkan dengan rotary evaporator sampai diperoleh ekstrak kental. Formulasi losion ekstrak buah jamblang dibuat dengan metode continental. Dilakukan pengujian terhadap sifat fisik losion meliputi organoleptis, homogenitas, viskositas, daya sebar, dan kemampuan tabir surya. Rendemen ekstrak buah jamblang sebesar $18,10 \%$. Hasil pengamatan organoleptis menunjukkan warna ekstrak merah keunguan yang menunjukkan adanya antosianin pada lempeng KLT dengan hRf 16 dan berwarna mauve. Formula losion yang dihasilkan homogen dengan pH 6-7 dan viskositas 5460-4840 cP. Daya sebar dan daya lekat belum memenuhi persyaratan yaitu $>7$. Nilai SPF dari ekstrak buah jamblang menurun setelah dibuat sediaan losion.
\end{abstract}

Kata kunci: jamblang, losion tabir surya, SPF , Syzygium cumini (L.) Skeels, uji sifat fisik. 


\begin{abstract}
The prevalence of skin cancer in Indonesia is reported to be 5.9-7.8\%, which might be related to the high exposure of UV light to the skin. The use of sunscreen with protective skin ingredients is needed. The value of the sun protection factor of java plum (Syzygium cumini (L.) Skeels) fruit extract was $2.278 \pm 0.25 \%$, which is potentially formulated further into sunscreen preparation. The dried java plum fruits were powdered and sieved at 40/60 mesh to obtain the crude drugs. A total of $100 \mathrm{~g}$ of crude drugs was remacerated in $37 \% \mathrm{HCl}$-acidified $70 \%$ ethanol $(\mathrm{pH}$ 1) for $3 \times 24 \mathrm{~h}$. The extract was concentrated with a rotary evaporator until a thick extract was obtained. The java plum extract was formulated into lotion preparation by continental emulsions method. The physical properties of lotions, i.e., organoleptic, homogeneity, viscosity, and spreadability, as well as sunscreen effectivity were evaluated accordingly. The yield of java plum fruit extract was $18.10 \%$, which occurred as purplish-red in color. The anthocyanins were observed on TLC analysis as a spot with a hRf value of 16 and mauve in color. The obtained lotion was homogeneous with the $\mathrm{pH}$ and viscosity of 6-7 and 5460-4840 CP, respectively. The spreadability of the lotion (>7) was not within the required standard. The formulation of java plum fruit extract into sunscreen decreased the SPF value.
\end{abstract}

Key words: java plum, physical properties, SPF, sunscreen lotion, Syzygium cumini (L.) Skeels.

\section{Pendahuluan}

Paparan radiasi sinar matahari yang berlebihan dapat berdampak buruk terhadap kesehatan kulit. Berbagai macam masalah atau penyakit dapat timbul seperti kulit kemerahan, kulit kering, kulit terbakar, kulit keriput, kerusakan kulit, iritasi, serta penyebab kanker kulit (D'Orazio et al., 2013; van der Rhee \& de Vries, 2008). Badan Kesehatan Dunia (WHO) memperkirakan di seluruh dunia ada sekitar 2 juta kasus baru kanker kulit non melanoma setiap tahun, sedangkan kanker kulit jenis melanoma sekitar 132.000 kasus baru setiap tahunnya (Armstrong \& Kricker, 2001). Center of Diseases Control (CDC) memperkirakan pada tahun 2005 di Amerika Serikat ada sekitar lebih kurang 53.792 orang didiagnosa terkena kanker kulit melanoma dan sekitar 8.345 orang meninggal dunia (Bray et al., 2018). Sedangkan American Cancer Society mengestimasi bahwa pada tahun 2008, 1000-2000 orang Amerika meninggal dunia disebabkan kanker kulit sel basal dan squamosa (Armstrong \& Kricker, 2001; Buller et al., 2011; Gloster \& Neal, 2006). Di Indonesia kanker kulit dijumpai sekitar 5,9-7,8\% dari keseluruhan jenis penyakit kanker (Smart Patients, 2017) dan menempati urutan ke-3 dari keseluruhan jenis kanker yang ada di Indonesia (Naldi \& Diepgen, 2007; Bott, 2014; Smart Patients, 2017).

Dari berbagai kejadian kanker yang diakibatkan paparan sinar UV tersebut diperlukan bahan pelindung 
yang diaplikasikan kepada kulit salah satunya dengan penggunaan tabir surya (Sarkany, 2017). Tabir surya berefek melindungi tubuh dari paparan sinar radiasi UV dengan cara menyerap sinar dalam kurun waktu tertentu yang dinilai sebagai sun protection factor (Lautenschlager et al., 2007; Kosmetik Konzept KOKO GmbH \& Co.KG, 2010).

Telah banyak penelitian tentang herbal yang bermanfaat sebagai tabir surya (Saewan \& Jimtaisong, 2013). Hal ini karena bahan alam tersebut banyak memiliki kandungan aktif alami seperti flavonoid (Pietta, 2000; Saric \& Sivamani, 2016) dan antosianain yang dapat melindungi kulit dari dampak buruk sinar UV (Saati et al., 2016; Wang \& Stoner, 2008). Buah jamblang (Syzygium cumini (L.) Skeels) memiliki kandungan vitamin yang larut dalam air seperti asam askorbat, tiamin, dan niacin (Ayyanar \& Subash-babu, 2012). Telah terbukti bahwa niacin secara signifikan juga dapat mengurangi kejadiaan tumor yang diinduksi oleh sinar UV (Park et al., 2018).

Telah banyak penelitian tentang sediaan tabir surya dari bahan alam tetapi masih jarang penelitian pada buah jamblang. Pada penelitian terdahulu tentang buah jamblang menyebutkan bahwa buah jamblang dilaporkan memiliki nilai faktor perlindungan matahari yaitu 2,278 $\pm 0,25 \%$ (Baghel et al., 2016). Losion adalah sediaan cair berupa suspensi atau dispersi, digunakan sebagai obat luar yang mudah digunakan dan merata di permukaan kulit, dapat berupa suspensi zat padat dalam bentuk serbuk halus dengan bahan pensuspensinya yang cocok atau emulsi tipe minyak dalam air (o/w atau w/o) dengan surfaktan yang cocok (Depkes RI, 1979).

\section{Metode Penelitian}

Alat dan Bahan

Alat yang digunakan dalam penelitian ini adalah timbangan analitik (Shimadzu ATX224, Jepang), pH meter (Metrohm, USA), spektrofotometer UVVis (Shimadzu UV-1800, Jepang), Alat gelas (Iwaki-Pyrex, USA). Bahan yang digunakan dalam penelitian ini adalah buah jamblang (Syzygium cumini L. (Skeels)), akuades, alfa tokoferol, cera alba, metilparaben, propilparaben, minyak mawar, setil alkohol, stearil alcohol, dan tween 80 .

\section{Jalannya Penelitian}

1. Penyiapan ekstrak

Bahan yang digunakan yaitu buah jamblang yang didapatkan dari Kampung Bulu, Desa Setia Mekar, Kecamatan Tambun Selatan, Kabupaten Bekasi, Provinsi Jawa Barat. Kemudian dilakukan Determinasi tanaman dilakukan di Laboratorium Lingkungan, Fakultas Biologi, Universitas Jendral Soedirman. Buah jamblang dicuci lalu dipisahkan dari bijinya dan kulitnya lalu dikeringkan pada suhu 40-60 ${ }^{\circ} \mathrm{C}$. Buah jamblang yang telah dikeringkan lalu dihaluskan dengan blender dan diayak pada 40/60 mesh lalu ditimbang untuk mendapatkan 
rendemen simplisia. Sebanyak $100 \mathrm{~g}$ serbuk diekstraksi dengan menggunakan metode remaserasi dengan pelarut etanol $70 \%$ selama $3 \times 24$ jam dan juga ditambahkan $\mathrm{HCl}$ $37 \%$ hingga $\mathrm{pH} 1$ dengan sesekali diaduk (Maran et al., 2015; Sari et al., 2012a). Maserat kemudian diserkai dan dipekatkan dengan rotary evaporator sampai diperoleh ekstrak kental.

2. Pembuatan losion

Pembuatan losion ekstrak buah jamblang mengikuti cara pembuatan emulsi continental (Gom Basah) dengan komposisi yang terdapat pada Tabel 1. Fase minyak (cera alba, setil alkohol, stearil alkohol, parafin cair, dan propilen paraben) dicampur dan dipanaskan pada suhu $65-75{ }^{\circ} \mathrm{C}$ di atas hotplate. Fase air (tween 80 dan metilparaben) juga dipanaskan pada suhu yang sama. Setelah homogen fase minyak ditambahkan ke dalam fase air dan diaduk sebentar, kemudian dituangkan ke dalam mortir sambil digerus. Akuades ditambahkan sedikit demi sedikit. Setelah dingin ditambahkan ekstrak buah jamblang, alfa tokoferol, dan minyak mawar secara berturut-turut. Proses penambahan bahan-bahan dilakukan sambil terus digerus hingga terbentuk massa losion yang homogen. Masing-masing formula dibuat triplo (Daud \& Al Hajri, 2016).

Tabel 1. Formula losion tabir surya ekstrak buah jamblang

\begin{tabular}{lcccc}
\hline \multirow{2}{*}{ Bahan } & \multicolumn{3}{c}{ Formula } & \multirow{2}{*}{ Kegunaan } \\
\cline { 2 - 4 } & F1 & F2 & F3 & \\
\hline Ekstrak etanol buah jamblang & $2,5 \%$ & 5 & 10 & Zat aktif \\
Cera alba & $7 \%$ & $7 \%$ & $7 \%$ & Stabilisator emulsi \\
Tween 80 & $7 \%$ & $7 \%$ & $7 \%$ & Emulgator \\
Setil alkohol & $3 \%$ & $3 \%$ & $3 \%$ & Pengemulsi, emolien \\
Stearil alkohol & $2 \%$ & $2 \%$ & $2 \%$ & Pengemulsi, emolien \\
Parafin cair & $10 \%$ & $10 \%$ & $10 \%$ & Pelembut \\
Metil paraben & $0,18 \%$ & $0,18 \%$ & $0,18 \%$ & Pengawet \\
Propil paraben & $0,02 \%$ & $0,02 \%$ & $0,02 \%$ & Pengawet \\
Minyak mawar & 3 tetes & 3 tetes & 3 tetes & Pewangi \\
Alfa tokoferol & 2 tetes & 2 tetes & 2 tetes & Antioksidan \\
Akuades ad & $100 \%$ & $100 \%$ & $100 \%$ & Pelarut \\
\hline
\end{tabular}

3. Uji viskositas

Pengukuran viskositas dilakukan dengan cara sediaan dimasukan ke dalam wadah berupa tabung silinder kaca (gelas piala) dan spindle yang sesuai dimasukkan sampai garis batas sampai jarum viskometer menunjukan skala yang konstan. Pengukuran ini dilakukan dengan tiga kali pengulangan. Syarat viskositas sediaan adalah 2000-50.000 Cps (Daud \& Al Hajri, 2016; Yumas et al., 2015).

4. Uji daya lekat 
Sebanyak 0,5 gram sediaan losion diletakkan di atas gelas obyek yang telah ditentukan luasnya. Gelas obyek yang lain diletakkan di atas losion tersebut. Kedua ujung objek glass dijepit dengan penjepit, lalu diberi beban 50 gram. Lama waktu hingga objek glass terlepas dihitung.

5. Uji daya sebar

Losion diambil dengan spatula dan dicetak dengan cara dimasukkan ke dalam lubang ring atau cincin (diameter 1,5 cm dan tebal 0,3 cm), kemudian sampel dihimpit dengan kaca transparan dan dicetak beban 200 g selama 3 menit, penyebaran losion pada kaca diukur diameternya. Daya sebar losion yang baik $5-7 \mathrm{~cm}$ (Daud \& Al Hajri, 2016; Hasibuan, 2014).

6. Uji stabilitas dipercepat (cycling test)

Uji dilakukan dengan menyimpan sediaan lotion pada suhu $5 \pm 2{ }^{\circ} \mathrm{C}$ selama 24 jam, lalu dipindahkan ke oven yang bersuhu $40 \pm 2{ }^{\circ} \mathrm{C}$ juga selama 24 jam. Perlakuan ini terhitung 1 siklus dan dilakukan sebanyak 6 siklus atau selama 12 hari (Daud \& Al Hajri, 2016).
7. Uji kemampuan tabir surya

Sampel losion dengan ekstrak buah jamblang dengan konsentrasi 2,5; 5; dan $10 \%$, serta losion blangko tanpa ekstrak sebanyak 0,5 g dilarutkan dalam $25 \mathrm{~mL}$ etanol 90\% (20.000 ppm). masing masing sampel diukur serapannya dengan alat spektrofotometer UV-Vis. Spektrum absorbansi diperoleh pada kisaran 290-320 nm, pada setiap interval 5 $\mathrm{nm}$ direplikasi 3 kali. Nilai SPF ditentukan menggunakan persamaan 1 (Dutra et al., 2004; Sayre et al., 1979). Nilai EE x 1 adalah suatu konstanta nilai dari panjang gelombang setiap selisih $5 \mathrm{~nm}$ dari 250-350 nm dan dapat dlihat pada Tabel 2. Kemampuan ini akan dibandingkan dengan nilai keefektifan tabir surya berdasarkan nilai SPF (Tabel 3).

$S P F=C F \sum_{290}^{320} E E(\lambda) \times I(\lambda) \times A(\lambda)$

Keterangan:

$\mathrm{EE}=$ spektrum efek eritema

$\mathrm{I}$ = spektrum intensitas sinar

$\mathrm{A}=$ absorbansi

CF = faktor koreksi (Sayre et al., 1979)

Tabel 2. Nilai EE x I pada 250-350 nm

\begin{tabular}{ll}
\hline Panjang gelombang $(\mathbf{n m})$ & EE x I \\
\hline 290 & 0,0150 \\
295 & 0,0817 \\
300 & 0,2874 \\
305 & 0,3278 \\
310 & 0,1864 \\
315 & 0,0839 \\
320 & 0,0180 \\
\hline
\end{tabular}


Tabel 3. Keefektifan tabir surya berdasarkan nilai SPF

\begin{tabular}{lc}
\hline SPF & Katagori Proteksi Tabir Surya \\
\hline $2-4$ & Proteksi minimal \\
$4-6$ & Proteksi sedang \\
$6-8$ & Proteksi Ekstra \\
$8-15$ & Proteksi Maksimal \\
$\geq 15$ & Proteksi Ultra \\
\hline
\end{tabular}

6. Analisis data

Data yang diperoleh dari hasil pengukuran nilai SPF sediaan dan sifat mutu sediaan seperti organoleptis, homogenitas, viskositas, $\mathrm{pH}$ sediaan, daya sebar, stabilatas sediaan diolah secara analisis statistik dengan SPSS 23 (IBM Inc., USA).

\section{Hasil dan Pembahasan}

Hasil determinasi tanaman menunjukkan sampel yang diambil benar-benar tanaman jamblang Syzygium cumini (L) skeels. Sampel yang digunakan menggunakan tanaman dan bagian tanaman utuh untuk dilakukan identifikasi menggunakan panduan referensi Bulletin: Bureau of Plant Industry. Determinasi bahan yang berupa tanaman merupakan tahap awal dari penelitian. Tujuan determinasi adalah untuk mendapatkan kebenaran identitas dengan jelas dari tanaman yang diteliti dan menghindari kesalahan atau kekeliruan (Dalimartha, 2003).

Buah jamblang segar dicuci bersih lalu dikeringkan dalam lemari pengering selama 1 (satu) minggu pada suhu optimum $40-60{ }^{\circ} \mathrm{C}$ dengan tujuan mencegah timbulnya jamur, kapang, atau bakteri serta menghentikan kerja enzim yang dapat merusak kualitas bahan. Buah jamblang kering diayak dengan ayakan nomer 40/60 agar diperoleh serbuk halus dan homogen. Penyerbukan dilakukan agar proses penyarian efektif dengan memperkecil ukuran partikel sehingga dapat memperluas permukaan kontak serbuk dengan penyari. Penelitian sebelumnya menyatakan ukuran partikel 40/60 memiliki luas permukaan kontak paling luas. Permukaan kontak serbuk simplisia dengan pelarut yang luas akan memaksimalkan kesempatanan pelarut untuk mengestraksi antosionin (Kwartiningsih et al., 2016; Sari et al., 2012b).

Proses ekstraksi dilakukan dengan cara remaserasi dengan etanol 70\% karena lebih sederhana, mudah, dan cocok untuk sampel yang tidak tahan terhadap pemanasan. Pemilihan penyari etanol karena harganya murah, mudah didapat, tidak toksik, mencegah pertumbuhan jamur dan memiliki kemampuan menyari senyawa pada rentang polaritas yang lebih lebar mulai dari senyawa polar hingga nonpolar (Sari et al., 2009, 2012b). Penambahan $\mathrm{HCl}$ $37 \%$ hingga $\mathrm{pH}$ nya 1 dengan tujuan agar senyawa seperti antosianin tetap stabil karena antosianin tidak stabil dalam kondisi basa dan penggunakan pelarut 
pH 1 karena senyawa fenolik lebih mudah terekstraksi pada pelarut yang memiliki pH rendah (Ayyanar \& SubashBabu, 2012; Sari et al., 2012a; VenuGopal et al., 2018). Cairan penyari akan menembus dinding sel dan masuk ke dalam rongga sel yang mengandung zat aktif. Zat aktif akan larut dan karena adanya perubahan konsentrasi antara larutan zat aktif di dalam sel dengan yang di luar sel, maka larutan yang pekat terdesak keluar. Peristiwa tersebut berulang sehingga terjadi keseimbangan konsentrasi antara larutan di luar sel dan di dalam sel. Maserat yang didapat kemudian dipekatkan dengan rotary vacum evaporator pada suhu $40^{\circ} \mathrm{C}$ dilanjutkan di waterbath untuk menguapkan cairan penyarinya sehingga didapatkan ekstrak kental. Diperoleh ekstrak sejumlah 18,10 g dengan rendemen 18,10\% (Benherlal \& Arumughan, 2007).

Dalam pembuatan formula losion mengikuti komposisi formula pada Tabel $5 . \quad$ Berdasarkan fungsi setiap bahan berturut-turut adalah ekstrak kental sebagai zat aktif, cera alba sebagai stabilisator emulsi, tween 80 berfungsi sebagai emulgator fase air, setil alkohol dalam sediaan losion digunakan sebagai penyerap air, bahan pengemulsi, pelembut sekaligus dapat meningkatkan tekstur, dan penambah kekentalan, parafin cair berfungsi sebagai pelembut, metil paraben berfungsi sebagai pengawet, propil paraben berfungsi sebagai pengawet, minyak mawar berfungsi sebagai pewangi, alfatokoferol digunakan sebagai antioksidan (Rowe et al., 2009). Losion dibuat 4 formulasi, kemudian semua formula dilakukan evaluasi sifat fisik secara organoleptis yang dapat dilihat dalam Tabel 5.

Uji organoleptis dilakukan dengan pengamatan secara visual meliputi warna, bau, dan bentuk sediaan losion. Pengamatan ini bertujuan untuk mengetahui losion yang dibuat sesuai dengan warna dan bau bahan yang digunakan. Hasil pengamatan organoleptik menunjukkan bahwa keempat formula losion tabir surya yang dibuat setelah cycling test dilakukan tidak stabil. Bentuk sediaan menjadi semakin cair dengan aroma khas mawar berkurang. Hal ini disebabkan oleh pengaruh oksigen dari udara, cahaya, serta panas-dingin (perubahan suhu ekstrem pada proses cycling test) terhadap komponen basis losion terutama fase minyak (Daud \& Al Hajri, 2016).

Tabel 4. Hasil warna dan nilai Rf identifikasi antosianin secara KLT

\begin{tabular}{cccccc}
\hline No & Pemisahan Noda & Nilai Rf (teori) x 100 & Nilai Rf & Warna (teori) & Warna terbentuk \\
\hline 1 & Noda 1 & 15 & 16 & Mauve & Mauve \\
2 & Noda 2 & 26 & 26 & Magenta & Magenta \\
3 & Noda 3 & 37 & 36 & Magenta & Magenta \\
\hline
\end{tabular}


Vol.17 No. 01 Juli 2020:225-240

Tabel 5. Hasil uji organoleptis losion ekstrak buah jamblang

\begin{tabular}{lccc}
\hline Parameter & Formulasi & Sebelum cycling test & Sesudah cycling test \\
\hline Bentuk & F1 & Semi padat & Semi padat (lebih cair) \\
& F2 & Semi padat & Semi padat (lebih cair) \\
& F3 & Semi padat & Semi padat (lebih cair) \\
& F4 & Semi padat & Semi padat (lebih cair) \\
\hline Warna & F1 & Putih & Putih \\
& F2 & Putih kecoklatan & Putih kecoklatan \\
& F3 & Putih kecoklatan & Putih kecoklatan \\
& F4 & Putih keabu-abuan & Putih keabu-abuan \\
\hline Bau & F1 & Khas minyak mawar & Khas minyak mawar lemah \\
& F2 & Khas minyak mawar & Khas minyak mawar lemah \\
& F3 & Khas minyak mawar & Khas minyak mawar lemah \\
& F4 & Khas minyak mawar & Khas minyak mawar lemah \\
\hline
\end{tabular}

Keterangan: F1=dengan ekstrak 0,05\%, F2=dengan ekstrak 0,1\%, F3=dengan ekstrak 0,15\%, F4=kontrol negatif.

Uji homogenitas bertujuan untuk kesempurnaan pencampuran dalam sediaan karena homogen atau tidaknya suatu sediaan dapat berpengaruh terhadap homogenitas zat aktif yang digunakan (Kuncari et al., 2014). Hasil pengujian homogenitas sebelum cycling test menunjukkan bahwa keempat formula tersebut homogen karena tidak terdapat partikel-partikel kasar pada losion yang menunjukkan bahwa komponen bahan formula losion tersebut tercampur homogen. Hasil uji setelah cycling test menunjukkan keempat formula tersebut tetap stabil dan homogen yang dapat dilihat pada Tabel 6.

Uji derajat $\mathrm{pH}$ bertujuan untuk menentukan apakah sediaan losion memenuhi persyaratan sediaan topikal yang baik. $\mathrm{pH}$ yang terlalu basa dapat menyebabkan kulit bersisik, sedangkan jika pH terlalu asam maka mengakibatkan iritasi pada kulit. $\mathrm{pH}$ ideal dalam sediaan tabir surya berkisar antara 4,5-8 (SNI, 1996). Hasil pengukuran losion dapat dilihat di dalam Tabel 7.

Pengukuran $\mathrm{pH}$ dilakukan menggunakan $\mathrm{pH}$ meter. Nilai $\mathrm{pH}$ ditentukan berdasarkan nilai yang ditampilkan pada layar. Dari hasil uji pH (Tabel 6), pengukuran $\mathrm{pH}$ sebelum dan sesudah cycling test untuk formula F1, F2, F3, dan F4 memenuhi syarat untuk sediaan tabir surya karena hasilnya berkisar 4,5-8. Data pH selanjutnya dianalisis menggunakan Kruskal-Wallis yaitu untuk mengetahui ada tidaknya perbedaan yang signifikan antara sebelum dan sesudah cycling test. Dari kruskal wallis diperoleh hasil ada perbedaan yang signifikan $p<0,05$, yang berarti waktu penyimpanan berpengaruh terhadap $\mathrm{pH}$ losion. Hal ini dapat dijelaskan karena adanya ketidakstabilan komposisi dalam formula, karena media yang terdekomposisi karena perubahan suhu dan faktor lingkungan serta adanya 
oksidasi pada bahan (Putra et al., 2017). Selanjutnya berdasarkan uji MannWhitney, menunjukkan bahwa $\mathrm{pH}$ sediaan losion terdapat perbedaan yang signifikan $p<0,05$.

Uji viskositas dilakukan untuk mengetahui tingkat kekentalan dari sediaan yang dihasilkan. Viskositas merupakan pernyataan dari suatu cairan untuk mengalir. Semakin tinggi nilai viskositasnya maka semakin sulit untuk mengalir atau semakin besar tahanannya. Hasil pengukuran viskositas pada keempat formula tersebut menghasilkan nilai viskositas yang berbeda yang bisa dilihat pada Tabel 8 . Dimana terjadi penurunan nilai viskositas dari keempat formula tersebut. Akan tetapi nilai viskositas yang dihasilkan tidak melebihi nilai viskositas yang di persyaratkan SNI 16-4399-1996 untuk sediaan tabir surya yaitu 2000-50.000 cps (SNI, 1996).

Pada penelitian ini terjadi penurunan viskositas yang dapat disebabkan oleh beberapa hal antara lain faktor pencampuran atau pengadukan emulsi, konsentrasi zat pengental, dan perubahan suhu yang ekstrim selama uji cycling test (Putri et al., 2019). Dari uji Kruskal-Wallis diperoleh hasil nilai $p=0,000$ yang berarti $p<0,05$. Selanjutnya berdasarkan uji Mann-Whitney, menunjukkan bahwa viskositas sediaan losion terdapat perbedaan yang signifikan $\mathrm{p}<0,05$ menandakan adanya perbedaan bermakna yang berarti waktu penyimpanan berpengaruh terhadap viskositas losion. Hal ini bisa disebabkan karena waktu penyimpanan akan berpengaruh terhadap stabilitas sediaan. Semakin lama waktu penyimpanan akan menyebabkan bergabungnya partikel tak larut membentuk aglomerat dan menyebabkan luas kontak partikel berkurang (Oktaviasari et al., 2017).

Tabel 6. Hasil uji homogenitas losion

\begin{tabular}{lcc}
\hline Formula & Sebelum cycling test & Sesudah cycling test \\
\hline F1 & Homogen & Homogen \\
F2 & Homogen & Homogen \\
F3 & Homogen & Homogen \\
F4 & Homogen & Homogen \\
\hline Keterangan: & F1=dengan ekstrak $0,05 \%, F 2=$ dengan ekstrak $0,1 \%, F 3=$ dengan ekstrak 0,15\%, \\
& F4=kontrol negatif. &
\end{tabular}

Tabel 7. Pengukuran $\mathrm{pH}$ sesudah dan sebelum cycling test

\begin{tabular}{lcc}
\hline Formula & Sebelum cycling test & Sesudah cycling test \\
\hline F1 & 6,25 & 7,75 \\
F2 & 6,26 & 7,77 \\
F3 & 6,29 & 7,81 \\
F4 & 6,20 & 7,66 \\
\hline
\end{tabular}


Vol.17 No. 01 Juli 2020:225-240

Keterangan: $F 1=$ dengan ekstrak $0,05 \%, F 2=$ dengan ekstrak $0,1 \%, F 3=$ dengan ekstrak $0,15 \%$, F4=kontrol negatif.

Tabel 8. Hasil uji viskositas losion ekstrak jamblang

\begin{tabular}{lcc}
\hline Formula & Sebelum cycling test & Sesudah cycling test \\
\hline F1 & $9,300 \mathrm{cps}$ & $5,460 \mathrm{cps}$ \\
F2 & $10,100 \mathrm{cps}$ & $5,840 \mathrm{cps}$ \\
F3 & $9,400 \mathrm{cps}$ & $4,900 \mathrm{cps}$ \\
F4 & $11,00 \mathrm{cps}$ & $4,840 \mathrm{cps}$ \\
\hline
\end{tabular}

Keterangan: $F 1=$ dengan ekstrak 0,05\%, F2=dengan ekstrak 0,1\%, F3=dengan ekstrak 0,15\%, F4=kontrol negatif.

Uji daya sebar losion bertujuan untuk mengetahui luasnya penyebaran losion pada saat dioleskan pada kulit, sehingga dapat dilihat kemudahan pengolesan sediaan losion ke kulit. Permukaan penyebaran yang dihasilkan dengan menaiknya pembebanan ditujukan untuk menggambarkan daya sebar (Voight, 1995). Untuk luas permukaan yang dihasilkan berbanding lurus dengan kenaikan beban yang ditambahkan (Hasibuan, 2014). Hasil uji daya sebar losion dapat dilihat pada Tabel 9. Berdasarkan hasil uji tersebut terlihat bahwa losion tidak memenuhi persyaratan uji daya sebar untuk sediaan topikal yang baik yaitu sekitar $5-7 \mathrm{~cm}$ karena daya sebar yang kurang akan mempengaruhi kontak antara obat dengan kulit (Wasitaatmadja, 1997).

Dari data pada Tabel 8, daya sebar dianalisis menggunakan KruskalWallis karena kedua syarat dari anova tidak terpenuhi. yaitu untuk mengetahui ada tidaknya perbedaan yang signifikan antara sebelum dan sesudah cycling test. Dari Kruskal-Wallis didapatkan hasil $p<0,05$ menandakan ada perbedaan yang bermakna. Hal ini menunjukkan bahwa perbedaan konsentrasi mempengaruhi diameter penyebaran. Selanjutnya berdasarkan uji MannWhitney, menunjukkan bahwa daya sebar sediaan losion terdapat perbedaan yang signifikan $p<0,05$ yang berarti perbedaan konsentrasi mempengaruhi diameter penyebaran.

Uji daya lekat bertujuan untuk mengetahui waktu yang dibutuhkan oleh sediaan losion untuk melekat pada kulit. Semakin lama waktu yang dibutuhkan losion untuk melekat maka semakin lama daya kerja obat. Daya lekat losion dipengaruhi oleh viskositas, dimana semakin tinggi viskositas maka semakin lama waktu melekat losion pada kulit. Syarat waktu daya lekat yang baik untuk sediaan topikal adalah lebih dari 4 detik (Wasitaatmadja, 1997) Hasil uji daya lekat dapat dilihat pada Tabel 10.

Hasil uji daya lekat menunjukkan bahwa sediaan losion dari keempat formula tidak memenuhi syarat. Daya lekat yang tidak memenuhi syarat akan mempengaruhi daya lekat pada kulit yang menjadi tidak maksimal. Dari hasil 
Vol.17 No. 01 Juli 2020:225-240

analisis menggunakan Kruskal-Wallis untuk sediaan losion tabir surya ekstrak buah jamblang didapatkan hasil bahwa daya lekat pada masing-masing formula terdapat perbedaan yang signifikan karena $p<0,05$. Selanjtnya berdasarkan hasil uji Mann-Whitney, bahwa daya lekat sediaan menunjukkan terdapat perbedaan yang signifikan $p<0,005$ maka dapat disimpulkan konsentrasi ekstrak buah jamblang mempengaruhi daya lekat.

Tabel 9. Hasil uji daya sebar losion

\begin{tabular}{lcccccccc}
\hline \multirow{2}{*}{ Formula } & \multicolumn{3}{c}{ Diameter sebelum } & Cycling Test $(\mathbf{c m})$ & \multicolumn{3}{c}{ Diameter sesudah Cycling Test (cm) } \\
\cline { 2 - 8 } & $\mathbf{0 ~ g}$ & $\mathbf{5 0} \mathbf{g}$ & $\mathbf{1 0 0} \mathbf{~ g}$ & $\mathbf{1 5 0} \mathbf{~}$ & $\mathbf{0 ~ g}$ & $\mathbf{5 0} \mathbf{g}$ & $\mathbf{1 0 0} \mathbf{~}$ & $\mathbf{1 5 0} \mathbf{~}$ \\
\hline F1 & 4,25 & 3,55 & 3,9 & 4,12 & 7,05 & 7,25 & 7,6 & 7,9 \\
F2 & 4,12 & 3,32 & 3,8 & 3,8 & 6,85 & 7,3 & 7,3 & 7,5 \\
F3 & 3,5 & 3,7 & 3,9 & 3,9 & 7,25 & 8,12 & 9,25 & 9,42 \\
F4 & 3,40 & 3,55 & 3,9 & 4,12 & 5,3 & 6,3 & 7,5 & 7,6 \\
\hline
\end{tabular}

Keterangan: $\mathrm{F} 1=$ dengan ekstrak 0,05\%, F2=dengan ekstrak 0,1\%, F3=dengan ekstrak 0,15\%, F4=kontrol negatif.

Tabel 10. Hasil uji daya lekat losion

\begin{tabular}{lcc}
\hline Formula & Sebelum Cycling Test (detik) & Sesudah Cycling Test (detik) \\
\hline F1 & 1,35 & 1,0 \\
F2 & 1,05 & 0,98 \\
F3 & 0,98 & 0,88 \\
F4 & 1,67 & 1,05 \\
\hline
\end{tabular}

Keterangan: F1=dengan ekstrak 0,05\%, F2=dengan ekstrak 0,1\%, F3=dengan ekstrak 0,15\%, $\mathrm{F} 4=$ kontrol negatif.

Hasil pengukuran nilai SPF sediaan losion dapat dilihat pada Tabel 11. Dari hasil perhitungan didapatkan nilai SPF terbesar adalah 1,53 yang terdapat dalam formula 3. Hasil ini menunjukkan keefektifannya sebagai tabir surya rendah, karena masuk dalam kategori tabir surya dengan perlindungan minimal. Besarnya kemampuan suatu senyawa untuk melindungi kulit dari radiasi UV dapat dilihat dari nilai SPF ini. Semakin tinggi nilai SPF, semakin efektif aktivitas tabir surya suatu sediaan (Dutra et al., 2004). Hasil pengukuran SPF losion buah jamblang dapat dilihat pada Tabel 11 .
Berdasarkan hasil pengukuran SPF losion ekstrak buah jamblang dapat disimpulkan bahwa semakin tinggi konsentrasi ekstrak maka semakin tinggi juga nilai SPFnya. Hal ini disebabkan karena ekstrak yang mengandung banyak antosianin dapat menyerap sinar UV dengan baik sehingga tidak mengenai tubuh. Adanya ikatan rangkap terkonjugasi pada gugus kromofor yang terdapat dalam struktur antosianin membuat antosianin dapat menyerap cahaya pada daerah sinar tampak sehingga memungkinkan analisis pigmen tersebut secara spektroskopi. Makin banyak dan panjang susunan ikatan 
rangkap terkonjugasi pada struktur lebih panjang hal tersebut dapat antosianin, warna yang dihasilkan pada digambarkan pada salah satu senyawa tanaman akan semakin kuat dan antosianin di buah black current pada mengakibatkan penyerapan cahaya UV- Gambar 1.

Vis terjadi pada panjang gelombang yang

Tabel 11. Hasil pengukuran SPF losion tabir surya ekstrak buah jamblang

\begin{tabular}{ll}
\hline Formula & SPF \\
\hline F1 & 0,10 \\
F2 & 1,27 \\
F3 & 1,53 \\
F4 & 0,02 \\
\hline
\end{tabular}

Keterangan: $\mathrm{F} 1=$ dengan ekstrak 0,05\%, F2=dengan ekstrak 0,1\%, F3=dengan ekstrak 0,15\%, F4=kontrol negatif.

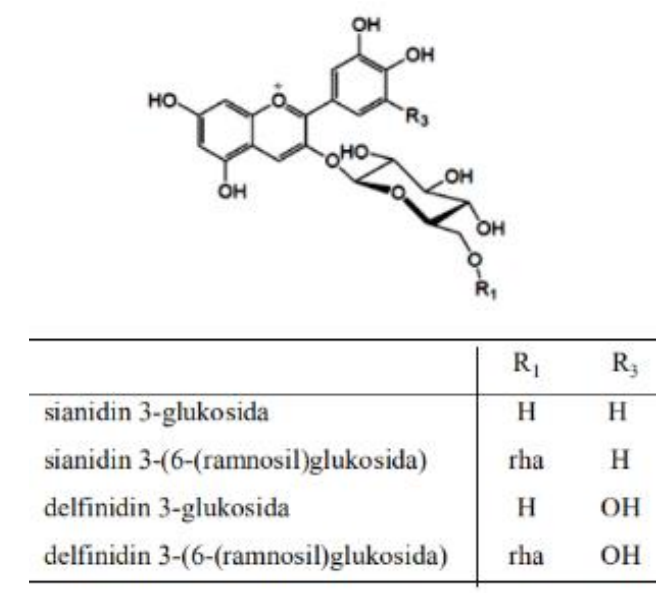

Gambar 1. Senyawa antosianidin.

Syarat sebagai tabir surya dalam SNI 16-4399-1996 minimal 4 (SNI, 1996). Antosianin merupakan komponen flavonoid dalam golongan fenol yang memiliki potensi sebagai tabir surya karena memiliki gugus kromofor. Gugus kromofor tersebut merupakan sistem aromatik terkonjugasi dimana saat terkena sinar UV akan terjadi resonansi dengan cara transfer elektron. Hal ini menyebabkan kemampuan untuk menyerap sinar pada gelombang sinar UV. Nilai SPF antosianin dari ekstrak buah jamblang jika dibandingkan dengan nilai SPF setelah dibuat sediaan losion terjadi penurunan. Adanya penurunan nilai SPF kemungkinan disebabkan karena konsentrasi ekstrak dalam sediaan yang terlalu sedikit, dan bahanbahan yang digunakan dalam formulasi telah menutupi aktivitas ekstrak sebagai tabir surya (Wulandari et al., 2018). Nilai 
$\mathrm{pH}$ sediaan losion yang cenderung basa juga berpengaruh karena ekstrak buah jamblang tidak stabil dalam suasana basa sehingga bisa terdegradasi dan menyebabkan penurunan nilai SPF. Berdasarkan data nilai SPF pada Tabel 11 yang dianalisis menggunakan oneway anova didapatkan bahwa terdapat perbedaan yang signifikan $p<0,05$ antara masing-masing formula. Selanjutnya berdasarkan uji post hoc tukey HSD terdapat perbedaan yang signifikan antara masing-masing formula $p<0,05$, maka dapat disimpulkan bahwa perbedaan konsentrasi ekstrak buah jamblang berpengaruh terhadap nilai SPF pada sediaan losion.

\section{Simpulan}

Formula losion yang dihasilkan rata-rata memiliki karakteristik fisik yang baik dengan tampilan homogen dengan $\mathrm{pH}$ 6-7 dan viskositas 5460-4840 cP. Daya sebar dan daya lekat belum memenuhi persyaratan. Nilai SPF dari ekstrak buah jamblang menurun setelah dibuat sediaan losion yang berarti belum bisa melindungi kulit dan perlu dilakukan penyempurnaan dalam pembuatannya.

\section{Daftar Pustaka}

Armstrong, B.K., Kricker, A. 2001. The epidemiology of UV induced skin cancer. Journal of Photochemistry and Photobiology B: Biology, 68(13):8-18.

Ayyanar, M., Subash-Babu, P. 2012. Syzygium cumini (L.) Skeels: a review of its phytochemical constituents and traditional uses. Asian Pacific Journal of Tropical Biomedicine, 2(3):240246.

Baghel, P., Wamankar, S., Gupta, A., Kashyap, P. Kaur, C. D. 2016. An assessment of antioxidant potential and in-vitro SPF activity of Euginia jambolana and Beta vulgaris. International Research Journal of Pharmacy, 7(5):42-47.

Benherlal, P.S. Arumughan, C. 2007. Chemical composition and in vitro antioxidant studies on Syzygium cumini fruit. Journal of the Science of Food and Agriculture, 87(14):2560-2569.

Naldi, W.L., Diepgen, T. 2007. The Epidemiology of Skin Cancer. In Photodermatology. Eds Lim, H.W., Honigsmann, H., Hawk, J.L.M. Boca Raton: CRC Press.

Bott, R. 2014. Data dan informasi kesehatan situasi penyakit kanker. Igarss, 2014(1):1-5.

Bray, F., Ferlay, J., Soerjomataram, I., Siegel, R.L., Torre, L.A., Jemal, A. 2018. Global cancer statistics 2018: GLOBOCAN estimates of incidence and mortality worldwide for 36 cancers in 185 countries. CA: A Cancer Journal for Clinicians, 68:394-424.

Buller, D.B., Cokkinides, V., Hall, H.I., Hartman, A.M., Saraiya, M., Miller, E., Paddock, L., Glanz, K. 2011. Prevalence of sunburn, sun protection, and indoor tanning behaviors among Americans: review from national surveys and case studies of 3 
states. Journal of the American Academy of Dermatology, 65(5 Suppl 1):S114-123.

D'Orazio, J., Jarrett, S., Amaro-Ortiz, A., Scott, T. 2013. UV radiation and the skin. International Journal of Molecular Sciences, 14(6):12222-12248.

Dalimartha, S. 2003. Atlas Tumbuhan Obat Indonesia Jilid 3. $3^{\text {rd }}$ ed. Jakarta: Puspa Swara.

Daud, N.S., Al Hajri, L.O.Z 2016. Formulasi lotion tabir surya ekstrak etanol beras merah (Oryza nivara). Jurnal IImiah Ibnu Sina, 1(2):143-150.

Depkes RI. 1979. Farmakope Indonesia, III. Jakarta: Depkes RI.

Dutra, E.A., da Costa, E., Oliveira, D.A.G., Kedor-Hackmann, E.R.M Miritello Santoro, M.I.R. 2004. Determination of sun protection factor (SPF) of sunscreens by ultraviolet spectrophotometry. Revista Brasileira de Ciencias Farmaceuticas/Brazilian Journal of Pharmaceutical Sciences, 40(3):381-385.

Gloster, H.M., Neal, K. 2006. Skin cancer in skin of color. Journal of the American Academy of Dermatology, 21(4):170-178.

Hasibuan, R.K. 2014. Formulasi dan uji sifat fisikokimia sediaan losio dengan berbagai variasi konsentrasi vitamin E. Skripsi. Program Studi Farmasi, Fakultas Kedokteran, Universitas Tanjung Pura.
Kuncari, E.S., Iskandarsyah, Praptiwi. 2014. Evaluasi, uji stabilitas fisik dan sineresis sediaan gel yang mengandung minoksidil, apigenin, dan perasan herba seledri (Apium graveolens L.). Buletin Penelitian Kesehatan, 42(4):213-222.

Kwartiningsih, E., Prastika, K.A., Triana, D.L. 2016. Ekstraksi dan uji stabilitas antosianin dari kulit buah naga super merah (Hylocereus costaricensis). Prosiding Seminar Nasional Teknik Kimia Kejuangan, Pengembangan Teknologi Kimia untuk Pengolahan Sumber Daya Alam Indonesia. 17 Maret 2016, Yogyakarta.

Lautenschlager, S., Wulf, H.C., Pittelkow, M.R. 2007. Photoprotection. The Lancet, 370(9586):528-537.

Mahmudatussa'adah, A., Fardiaz, D., Andarwulan, N., Kusnandar, F. 2014. Color characteristics and antioxidant activity of anthocyanin extract from purple sweet potato. Jurnal Teknologi dan Industri Pangan, 25(2):176184.

Maran, J.P., Sivakumar, V., Thirugnanasambandham, K., Sridhar, R. 2015. Extraction of natural anthocyanin and colors from pulp of jamun fruit. Journal of Food Science and Technology, 52(6):3617-3626.

Oktaviasari, L., Zulkarnain, A.K., Mada, U.G. 2017. Formulasi dan uji stabilitas fisik sediaan lotion O/W pati kentang (Solanum tuberosum L.) serta aktivitasnya 
sebagai tabir surya. Majalah Farmaseutik, 13(1):9-27.

Park, S.M., Li, T., Wu, S., Li, W., Weinstock, M., Qureshi, A., Cho, E. 2018. Niacin intake and risk of skin cancer in US women and men. International Journal of Cancer, 140(9):2023-2031.

Pietta, P.G. 2000. Flavonoids as antioxidants. Journal of Natural Products, 63(7):1035-1042.

Putra, M., Dewantara, I., Swastini, D. 2017. Pengaruh lama penyimpanan terhadap nilai $\mathrm{pH}$ sediaan cold cream kombinasi ekstrak kulit buah manggis (Garcinia mangostana L.), herba pegagan (Centella asiatica), dan daun gaharu (Gyrinops versteegii (gilg) Domke). Jurnal Farmasi Udayana, 3(1):18-21.

Putri, Y.D., Kartamihardja, H., Lisna, I. 2019. Formulasi dan evaluasi losion tabir surya ekstrak daun stevia (Stevia rebaudiana Bertoni M). Jurnal Sains Farmasi \& Klinis, 6(1):32-36

van der Rhee, H.J., de Vries, E. 2008. Radiation. in ESMO Handbook of Cancer Prevention. Eds Schrijvers, D., Senn, H., Mellstedt, H., Zakotnik, B London: Informa Healthcare.

Rowe, R.C., Sheskey, P.J., Quinn, M.E. 2009. Handbook of Pharmaceutical Excipients. $6^{\text {th }}$ ed. London: Pharmaceutical Press and American.

Saati, E.A., Asiyah, R., Ariesandy, M. 2016. Pigmen Antosianin:
Identifikasi dan Manfaatnya Bagi Industri Makanan dan Farmasi. Malang: Universitas Muhammadiyah Malang, Malang.

Saewan, N., Jimtaisong, A. 2013. Photoprotection of natural flavonoids. Journal of Applied Pharmaceutical Science, 3(9):129-141.

Sari, P., Wijaya, C.H., Sajuthi, D., Supratman, U. 2012a. Colour properties, stability, and free radical scavenging activity of jambolan (Syzygium cumini) fruit anthocyanins in a beverage model system: natural and copigmented anthocyanins. Food Chemistry, 132(4):19081914.

Sari, P., Wijaya, C.H., Sajuthi, D. Supratman, U. 2012b. Colour properties, stability, and free radical scavenging activity of jambolan (Syzygium cumini) fruit anthocyanins in a beverage model system: natural and copigmented anthocyanins. Food Chemistry, 132(4):19081914.

Sari, P., Wijaya, C.H., Sajuthi, D., Supratman, U. 2009. Identifikasi antosianin buah duwet (Syzygium cumini) menggunakan kromatografi cair kinerja tinggidiode array detection. Jurnal Teknologi dan Industri Pangan, 20(2):102-108.

Saric, S., Sivamani, R.K. 2016. Polyphenols and sunburn. International Journal of Molecular Sciences, 17(9):1-22. 
Sarkany, R. 2017. Sun protection strategies. Photoprotection of the Skin, 45(7):444-447.

Sayre, R.M., Agin, P.P., Levee, G.J. Marlowe, E. 1979. A comparison of in vivo and in vitro testing of sunscreening formulas. Photochemistry and Photobiology, 29:559-566.

Singh, B., Singh, J.P., Kaur, A., Singh, N. 2018. Insights into the phenolic compounds present in jambolan (Syzygium cumini) along with their health-promoting effects. International Journal of Food Science and Technology, 53(11):2431-2447.

SNI 16- 4399-1996. Sediaan Tabir Surya. Jakarta: Dewan Standardisasi Nasional.

Kosmetik Konzept KOKO GmbH \& Co.KG. 2010. Sun protection: on the efficiency of UV filters. Kosmetische Praxis, 2010(2):1013.

Smart Patients. 2017. Kanker kulit. https://www21.ha.org.hk/smart patient/EM/MediaLibraries/EM/ Diseases/Cancer/Skin Cancer/Cancer-Skin-CancerIndonesian.pdf?ext=.pdf. Data diakses pada 1 November 2019.
VenuGopal, K.S., Cherita, C., AnuAppaiah, K.A. 2018. Augmentation of chemical and organoleptic properties in Syzygium cumini wine by incorporation of grape seeds during vinification. Food Chemistry, 242: 98-105.

Voight, R. 1995. Buku Pelajaran Teknologi Farmasi. Penerjemah Soewandhi, S.N. Yogyakarta: Gajah Mada University Press.

Wang, L., Stoner, G.D. 2008. Anthocyanins and their role in cancer prevention. Cancer Letters, 269:281-290.

Wasitaatmadja, S.M. 1997. Penuntun IImu Kosmetik Medik. Jakarta: UI Press.

Wulandari, W., Wasito, H., Susilowati, S.S. 2018. Stabilitas fisik dan pengukuran nilai sun protection factor sediaan tabir surya pada kondisi stress penyimpanan dengan spektrofotometri. Acta Pharmaciae Indonesia, 6(1):111.

Yumas, M., Ramlah, S., Mamang. 2015. Formulasi lulur krim dari bubuk kakao non fermentasi dan efek terhadap kulit. Biopropal Industri, 6(2):63-72. 